
$\sum$ Research Square
Preprints are preliminary reports that have not undergone peer review.
They should not be considered conclusive, used to inform clinical practice,
or referenced by the media as validated information.

\title{
Renal Perivascular Epithelioid Cell Tumor with Lymph Nodes Metastasis: A Case Report and Literature Review
}

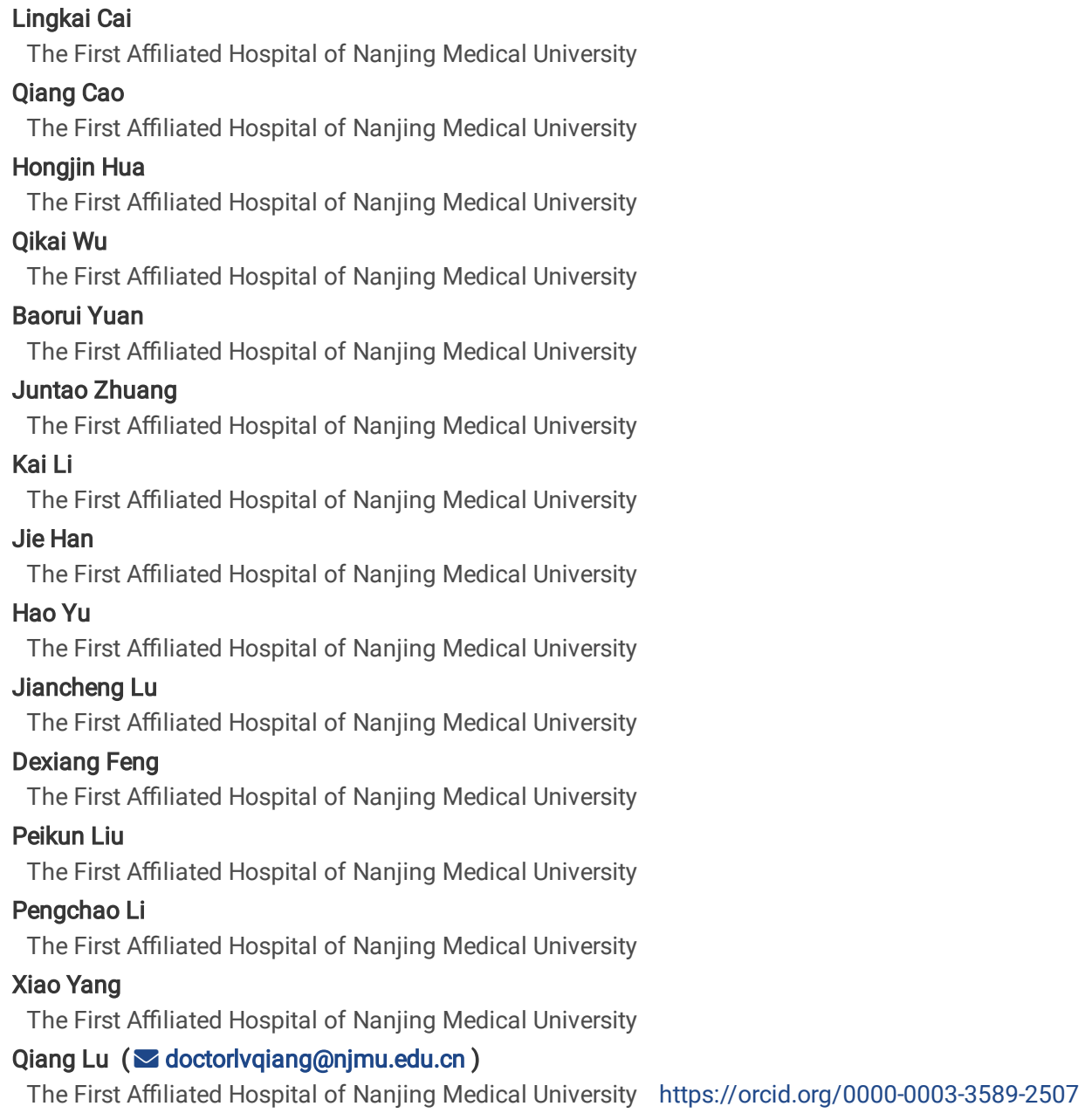

Case report

Keywords: PEComa, Angiomyolipoma, lymph node, metastasis

Posted Date: July 27th, 2021

DOI: https://doi.org/10.21203/rs.3.rs-733408/v1

License: @ (1) This work is licensed under a Creative Commons Attribution 4.0 International License. Read Full License 


\section{Abstract}

Background: Perivascular epithelioid cell tumor (PEComa) is mesenchymal tumor that originated from perivascular epithelioid cells. Angiomyolipoma (AML) is a common benign PEComa, composed of blood vessels, smooth muscle and mature adipose tissue. Epithelioid angiomyolipoma (EAML) is a rare subtype of AML that has the potential to be malignant.

Case presentation: The patient was a 42-year-old woman admitted to the hospital for her left low back swelling. The computed tomography angiography (CTA) revealed a $6.3^{\star} 5.5^{\star} 6.7 \mathrm{~cm}$ cystic-solid tumor in the intermediate kidney. Then we performed a left nephrectomy. Postoperative pathology showed that the tumor was angiomyolipoma (PEComa) with necrotic formation and was $6 \mathrm{~cm} * 6 \mathrm{~cm} \star 5.5 \mathrm{~cm}$ in size. Additionally, lymph nodes involved (4/17) were observed in the left renal hilum. Immunohistochemistry staining indicated that tumor cells focally expressed MelanA and HMB45. No evidence of disease progression at the six-month follow-up after surgery.

Conclusions: Lymph nodes involvement in renal PEComa was rare and was regarded as a type of metastasis. Lymph nodes metastasis might indicate a poor prognosis.

\section{Background}

Perivascular epithelioid cell tumor (PEComa) was first described in 1943, and it is a mesenchymal tumor that originated from perivascular epithelioid cells with the immunohistochemical characteristics of smooth muscle and melanocytes [1]. PEComa has been described in various anatomical locations. The liver, pancreas, uterus and kidney are frequently involved [2]. Additionally, the PEComa family includes angiomyolipoma (AML), pulmonary clear cell "sugar" tumor, lymphangiomyomatosis and soft-tissue clear cell myomelanocytic tumors, as well as other extremely rare malignancies [3]. Although the majority of PEComas have benign clinical characteristics, a small part of them have aggressive features and can evolve into distant metastases. At present, surgery is the primary technique of treating local diseases, and there is no universally accepted standard for postoperative adjuvant therapy [4]. Notably, mTOR inhibitors have been reported to be used in the treatment of advanced PEComa [5]. Here, we present a patient who suffered from malignant renal PEComa with renal hilum lymph nodes metastasis.

\section{Case Presentation}

The patient was a 42-year-old woman admitted to the hospital for 15 days because of left lumbus pain, but no positive signs were identified in the physical examination. She did not complain of hematuria, urinary tract irritation symptom, or dysuria and no abnormality was identified in laboratory examination. There was no history of tuberous sclerosis complex (TSC).

The computed tomography angiography (CTA) revealed a $6.3 \star 5.5 * 6.7 \mathrm{~cm}$ cystic-solid tumor in left kidney's middle and lower pole, with an obvious enhancement of solid components measuring approximately $1.8^{\star} 1.7 \mathrm{~cm}$ and a patchy hemorrhagic focus. The boundary of the mass is still visible." Then the "left nephrectomy" was performed, revealing several enlarged lymph nodes in the renal hilum, followed by renal hilar lymph node dissection. A solid mass with a clear border of approximately $6 \mathrm{~cm}$ was evident in the renal hilum, containing hemorrhagic and necrosis tissue.

"It is diagnosed as PEComa with necrotic formation, and tumor size was $6 \mathrm{~cm} \star 6 \mathrm{~cm} * 5.5 \mathrm{~cm}$, " according to postoperative pathology. Additionally, the lymph nodes involved (4/17) were seen in the left renal hilum. Besides, we observed that epithelioid component comprised around $30 \%$ of total. And the heterogeneity of some cells is evident, as evidenced by large and deep nucleus staining and an increase in the nuclear to cytoplasmic ratio. Necrosis was observed within the tumor. Immunohistochemistry staining showed that tumor cells expressed MelanA, Vimentin, SMA, and CD24 and were focally positive for HMB45 and CD10. Ki67 expression was detected in roughly $20 \%$ of tumor cells. However, tumor cells lacked Pax-8, S-100, and CK-pan expression. Within the six months follow-up post-operation, no disease recurrence and progression were identified.

\section{Discussion}

Angiomyolipoma (AML) is a common subtype of PEComa. It is composed of curved thick-walled blood vessels, smooth muscle, and adipocytes in varying proportions. And about $80-90 \%$ of renal AML occurs sporadically, usually isolated and unilateral [6, 7]. Some studies [8] have pointed out that AML is a common disease associated with tuberous sclerosis. Typical AML is a benign mesenchymal tumor. However, part of EAML tends to be malignant. EAML is extremely rare, accounting for about $5 \%$ of AML surgically removed [9]. Mai et al initially reported that renal AML with epithelioid morphology and its relation to AML [10] in 1996. Over 100 cases of EAML have been reported to date, however, the majority of them have benign results. At present, the pathogenesis of EAML is not clear, and there are no objective diagnostic criteria. We have recently treated a female patient who had been diagnosed as renal PEcoma with lymph node involvement.

Nalan et al [11] considered the EAML as a malignant tumor after evaluating the characteristics of numerous cases. Previous studies [11, 12] revealed that 20$30 \%$ of EAML patients developed metastasis and recurrence, with the liver, lung, and peritoneum being the most frequently implicated locations. However, the definition of the proportion of epithelioid components in EAML is not defined explicitly. Based on the literature review, the proportion of epithelioid cells ranged between $10 \%$ and $100 \%$, and studies indicated that more than $20 \%$ of epithelioid components are associated with recurrence and metastasis. The malignant risk seems to grow in direct proportion to the percentage of epithelioid components [13,14]. At present, rigorous diagnostic criteria for malignant renal PEComa has not been established. Pure et al [11] discovered that tumors linked with associated TSC, size $>7 \mathrm{~cm}$, necrosis, infiltrative growth, or vascular invasion were associated with disease progression. In our case, around $30 \%$ of the cells are epithelioid, and the heterogeneity of some cells is pronounced. As a result, this patient should be continuously monitored. 
Interestingly, there is no conclusive evidence that multiple AMLs are metastatic. Some researchers considered that multiple AMLs are polycentric in origin and that may be caused by the congenital presence of cell precursors in numerous locations [7] [15]. Tallarigo et al [16] considered that lymph nodes with regional or multiple involvements demonstrated multifocal development patterns rather than metastases. At present, there is no detailed research on the postoperative adjuvant therapy and prognostic factors of renal PEComa patient with lymph node involvement. Hence, we reviewed reported cases from 2001 to 2021 . As illustrated in Table 1, 16 cases of PEcoma with lymph node involvement have been recorded. Among them, 43.8\% (7/16) of patients experienced local recurrence or metastasis. The most common metastatic organs were the liver and lung. Besides, 6 out of 7 patients died, with a median PFS of 16 months. As shown, metastasis to lymph node may indicated a poor prognosis. However, we can only evaluate patients with lymph node metastasis retrospectively when they are reported and cannot combine them for additional analysis.

Table 1

The clinicopathological features and follow-up information of 16 malignant PEComa cases with lymph node metastasis from 2001 to 2020

\begin{tabular}{|c|c|c|c|c|c|c|c|c|c|c|c|c|c|}
\hline Cases & Age & Sex & TSC & Location & $\begin{array}{l}\text { Metastasis at } \\
\text { the time of } \\
\text { diagnosis }\end{array}$ & $\operatorname{Rec}$ & $\begin{array}{l}\text { Location of } \\
\text { metastasis }\end{array}$ & $\begin{array}{l}\text { Tumor } \\
\text { Size } \\
\text { (cm) }\end{array}$ & $\begin{array}{l}\text { Epithelioid } \\
\text { cells }\end{array}$ & $\begin{array}{l}\text { Number of } \\
\text { Mitosis/50 } \\
\text { HPF }\end{array}$ & $\begin{array}{l}\text { Renal vein } \\
\text { involvement }\end{array}$ & $\begin{array}{l}\text { Follow } \\
\text { up }\end{array}$ & $\begin{array}{l}\text { PFS } \\
\text { (mol }\end{array}$ \\
\hline 1 & 21 & $M$ & Yes & Both & $\begin{array}{l}\text { Liver, spleen, } \\
\text { peritoneum, } \\
\text { pleura; } \\
\text { retroperitoneal } \\
\text { lymph nodes }\end{array}$ & No & & $\begin{array}{l}0.5^{-} \\
17\end{array}$ & $>90 \%$ & NA & No & NA & NA \\
\hline 2 & 78 & $\mathrm{~F}$ & NA & Left & $\begin{array}{l}\text { Lung, bone, } \\
\text { regional lymph } \\
\text { node }\end{array}$ & No & & 12.5 & NA & NA & NA & Died & NA \\
\hline 3 & 31 & $\mathrm{~F}$ & Yes & Both & $\begin{array}{l}\text { Retroperitoneal } \\
\text { lymph nodes }\end{array}$ & No & & $1-10$ & $<50 \%$ & NA & Yes & Alive & NA \\
\hline 4 & 48 & $\mathrm{~F}$ & No & Right & $\begin{array}{l}\text { Retroperitoneal } \\
\text { lymph nodes }\end{array}$ & Yes & Liver, lung & 13 & NA & NA & Yes & Died & 16 \\
\hline 5 & 14 & $M$ & Yes & NA & Lymph nodes & No & & 11 & NA & 1 & NA & Alive & 24 \\
\hline 6 & 25 & $\mathrm{~F}$ & No & NA & Lymph nodes & Yes & $\begin{array}{l}\text { Peritoneal, } \\
\text { liver, lung }\end{array}$ & 8 & NA & 2 & NA & Died & 12 \\
\hline 7 & 67 & M & No & NA & Lymph nodes & No & & 15 & NA & 2 & NA & NA & NA \\
\hline 8 & 58 & M & No & NA & Lymph nodes & Yes & Liver & 37 & NA & 0 & NA & Died & 24 \\
\hline 9 & 55 & $\mathrm{~F}$ & No & NA & Lymph nodes & Yes & $\begin{array}{l}\text { Extensive } \\
\text { metastatic }\end{array}$ & 12.8 & NA & 4 & NA & Died & 12 \\
\hline 10 & 11 & $\mathrm{~F}$ & No & Left & Lymph nodes & No & & 10.5 & NA & NA & NA & Died & $\begin{array}{l}\text { seve } \\
\text { mon }\end{array}$ \\
\hline 11 & NA & NA & NA & NA & Lymph nodes & No & & NA & NA & NA & No & Alive & 36 \\
\hline 12 & 71 & $\mathrm{~F}$ & NA & NA & $\begin{array}{l}\text { Retroperitoneal } \\
\text { lymph nodes }\end{array}$ & No & & 9 & $10 \%$ & 1/10HPF & No & Alive & 54 \\
\hline 13 & 59 & M & NA & NA & $\begin{array}{l}\text { Retroperitoneal } \\
\text { lymph nodes }\end{array}$ & Yes & $\begin{array}{l}\text { Retroperitoneal } \\
\text { recurrence }\end{array}$ & 16 & $100 \%$ & 2/10HPF & Yes & Alive & 40 \\
\hline 14 & NA & NA & NA & NA & $\begin{array}{l}\text { Renal hilus } \\
\text { and para-aortic } \\
\text { Lymph nodes }\end{array}$ & Yes & Hepatic, lung & NA & $>90 \%$ & NA & NA & Died & 17 \\
\hline 15 & NA & NA & NA & NA & $\begin{array}{l}\text { Renal hilus } \\
\text { lymph nodes }\end{array}$ & Yes & $\begin{array}{l}\text { Local } \\
\text { recurrence }\end{array}$ & NA & $>90 \%$ & NA & NA & Died & 14 \\
\hline 16 & 42 & $\mathrm{~F}$ & NA & Left & Lymph nodes & No & & 6.7 & $30 \%$ & NA & No & Alive & 4 \\
\hline
\end{tabular}

F: Female, M: Male, Rec: Recurrence, TSC: Tuberous sclerosis complex, HPF: High power field, Ref: Reference,

Liu et al [17] analyzed the CT scan characteristics of EAMLs and discovered a tendency for super-attenuation on pre-contrast CT with or without fat components, as well as a dynamic enhancement-mode from rapid wash-in to slow wash-out. PEComa, mainly composed of epithelial cells, could be misdiagnosed as renal clear cell carcinoma if HMB45 and Melan-A are negative. HMB-45 and Melan A are the most sensitive immunohistochemical markers in PEComa [18]. In addition, renal PEcoma should be distinguished from pleomorphic rhabdomyosarcoma, malignant melanoma, alveolar soft part sarcoma, etc. Currently, tumor excision with negative tumor margins is still the recommended treatment strategy.

Many research indicated that malignant PEComa was associated with mutations in the TFE3 and P53 genes [19, 20]. Besides, activation of mTOR was related to the malignant potential of PEComa, for which mTOR inhibitors might be beneficial $[4,5]$. Thus, a multi-modal therapy strategy for PEComa with malignant potential should be explored. However, there are few publications discussing the options and efficacy of postoperative adjuvant therapy, indicating an urgent require for further research.

\section{Conclusions}


Lymph nodes involvement in renal PEComa was rare. Through the literature review, we believe that renal PECOma with lymph node involvement is a type of metastasis, which indicates the malignant potential of PEComa, and lymph node metastasis may indicate a poor prognosis. At present, patients with renal PEComa usually receive surgical treatment, But there is no standard postoperative adjuvant treatment, for such patients, postoperative adjuvant treatment may be beneficial to their prognosis.

\section{Abbreviations}

AML

Angiomyolipoma

CT

Computed tomography

\section{Declarations}

\section{Ethics approval and consent to participate}

All procedures performed in studies involving human participants were in accordance with the ethical standards of the Research Ethics Committee of The First Affiliated Hospital of Nanjing Medical University and with the 1964 Helsinki declaration and its later amendments. ALL written informed consent to participate in the study was obtained from the patient.

\section{Consent for publication}

All subjects have written informed consent; All presentations of case reports have consent for publication.

\section{Availability of data and material}

All data generated or analyzed during this study are included in this article.

\section{Competing interests}

The authors declare that they have no competing interests.

\section{Funding}

This work was supported by the National Natural Science Foundation of China (grantsNo.82072832,81772711), the "333" project of Jiangsu Province (LGY2016002), and Jiangsu Province's Key Provincial Talents Program (ZDRCA2016006).

The funder is corresponding author.

\section{Authors' contributions}

LC: made substantial contributions to the conception, design of the work, acquisition, analysis, interpretation of data and has drafted the work. QC: made substantial contributions to the interpretation of data and has substantially revised it. $\mathrm{HH}$ : made substantial contributions to the data collection. QW,BY: made substantial contributions to the picture editing. JZ,KL,JH: made substantial contributions to the Patient treatment and care. HY,JL,DF,PL,PL: made substantial contributions to the manuscript revision. XY,QL: made substantial contributions to the conception, design of the work, analysis. All authors read and approved the final manuscript.

\section{Acknowledgements}

Not applicable.

\section{References}

1. Hasan H, Howard AF, Alassiri AH, Ng TL, McGregor G, Goddard K. PEComa of the terminal ileum mesentery as a secondary tumour in an adult survivor of embryonal rhabdomyosarcoma. Curr Oncol. 2015;22:e383-6.

2. Vannucchi M, Minervini A, Salvi M, Montironi R, Raspollini MR. TFE3 Gene Rearrangement in Perivascular Epithelioid Cell Neoplasm (PEComa) of the Genitourinary Tract. Clin Genitourin Cancer. 2020;18:e692-7.

3. Bao L, Shi Y, Zhong J, Zhao M, Wu J, Hai L, Xu X, Du H, Shi Y. Histopathologic characteristics and immunotypes of perivascular epithelioid cell tumors (PEComa). Int J Clin Exp Pathol. 2019;12:4380-9.

4. Fabbroni C, Sbaraglia M, Sanfilippo R. Medical treatment of advanced malignant perivascular epithelioid cell tumors. Curr Opin Oncol. 2020;32:301-6.

5. Sanfilippo R, Fabbroni C, Fuca G, Fumagalli E, Morosi C, Sbaraglia M, Gronchi A, Collini P, Dei Tos AP, Casali PG. Addition of Antiestrogen Treatment in Patients with Malignant PEComa Progressing to mTOR Inhibitors. Clin Cancer Res. 2020;26:5534-8.

6. Lin WC, Wang JH, Wei CJ, Pan CC, Chang CY. Malignant renal epithelioid angiomyolipoma with aggressive behavior and distant metastasis. J Chin Med Assoc. 2003;66:303-6. 
7. Torigian DA, Kaiser LR, Soma LA, Tomaszewski JE, Kotloff R, Siegelman ES. Symptomatic dysrhythmia caused by a posterior mediastinal angiomyolipoma. AJR Am J Roentgenol. 2002;178:93-6.

8. El Jack AK, Tomaszewski JE, Haller DG, Siegelman ES. Metastatic PEComa arising from renal angiomyolipoma: MRI findings. J Magn Reson Imaging. 2007;26:159-61.

9. He W, Cheville JC, Sadow PM, Gopalan A, Fine SW, Al-Ahmadie HA, Chen YB, Oliva E, Russo P, Reuter VE, Tickoo SK. Epithelioid angiomyolipoma of the kidney: pathological features and clinical outcome in a series of consecutively resected tumors. Mod Pathol. 2013;26:1355-64.

10. Mai KT, Perkins DG, Collins JP. Epithelioid cell variant of renal angiomyolipoma. Histopathology. 1996;28:277-80.

11. Nese N, Martignoni G, Fletcher CD, Gupta R, Pan CC, Kim H, Ro JY, Hwang IS, Sato K, Bonetti F, et al. Pure epithelioid PEComas (so-called epithelioid angiomyolipoma) of the kidney: A clinicopathologic study of 41 cases: detailed assessment of morphology and risk stratification. Am J Surg Pathol. 2011;35:161-76.

12. Chuang CK, Lin HCA, Tasi HY, Lee KH, Kao Y, Chuang FL, Chang YH, Lin PH, Liu CY, Pang ST. Clinical presentations and molecular studies of invasive renal epithelioid angiomyolipoma. Int Urol Nephrol. 2017;49:1527-36.

13. Martignoni G, Pea M, Rigaud G, Manfrin E, Colato C, Zamboni G, Scarpa A, Tardanico R, Roncalli M, Bonetti F. Renal angiomyolipoma with epithelioid sarcomatous transformation and metastases: demonstration of the same genetic defects in the primary and metastatic lesions. Am $\mathrm{J}$ Surg Pathol. 2000;24:889-94.

14. Takahashi N, Kitahara R, Hishimoto Y, Ohguro A, Hashimoto Y, Suzuki T. Malignant transformation of renal angiomyolipoma. Int J Urol. 2003;10:271-3.

15. Lai HY, Chen CK, Lee YH, Tsai PP, Chen JH, Shen WC. Multicentric aggressive angiomyolipomas: a rare form of PEComas. AJR Am J Roentgenol. 2006;186:837-40.

16. Tallarigo C, Baldassarre R, Bianchi G, Comunale L, Olivo G, Pea M, Bonetti F, Martignoni G, Zamboni G, Mobilio G. Diagnostic and therapeutic problems in multicentric renal angiomyolipoma. J Urol. 1992;148:1880-4.

17. Liu Y, Qu F, Cheng R, Ye Z. CT-imaging features of renal epithelioid angiomyolipoma. World J Surg Oncol. 2015;13:280.

18. Calio A, Brunelli M, Segala D, Pedron S, Tardanico R, Remo A, Gobbo S, Meneghelli E, Doglioni C, Hes O, et al. t $(6 ; 11)$ renal cell carcinoma: a study of seven cases including two with aggressive behavior, and utility of CD68 (PG-M1) in the differential diagnosis with pure epithelioid PEComa/epithelioid angiomyolipoma. Mod Pathol. 2018;31:474-87.

19. Li J, Zhu M, Wang YL. Malignant epithelioid angiomyolipoma of the kidney with pulmonary metastases and p53 gene mutation. World J Surg Oncol. 2012;10:213.

20. Ohe C, Kuroda N, Hes O, Michal M, Vanecek T, Grossmann P, Tanaka Y, Tanaka M, Inui H, Komai Y, et al. A renal epithelioid angiomyolipoma/perivascular epithelioid cell tumor with TFE3 gene break visualized by FISH. Med Mol Morphol. 2012;45:234-7.

21. Radin R, Ma Y. Malignant epithelioid renal angiomyolipoma in a patient with tuberous sclerosis. J Comput Assist Tomogr. 2001;25:873-5.

22. Zhan R, Li YQ, Chen CY, Hu HY, Zhang C. Primary kidney malignant epithelioid angiomyolipoma: Two cases report and review of literature. Medicine. 2018;97:e11805.

23. Moudouni SM, Tligui M, Sibony M, Doublet JD, Haab F, Gattegno B, Thibault P. Malignant epithelioid renal angiomyolipoma involving the inferior vena cava in a patient with tuberous sclerosis. Urol Int. 2008;80:102-4. discussion 104.

24. Guo B, Song H, Yue J, Li G. Malignant renal epithelioid angiomyolipoma: A case report and review of the literature. Oncol Lett. 2016;11:95-8.

25. Rigby H, Yu W, Schmidt MH, Fernandez CV. Lack of response of a metastatic renal perivascular epithelial cell tumor (PEComa) to successive courses of DTIC based-therapy and imatinib mesylate. Pediatr Blood Cancer. 2005;45:202-6.

26. Aydin H, Magi-Galluzzi C, Lane BR, Sercia L, Lopez JI, Rini BI, Zhou M. Renal angiomyolipoma: clinicopathologic study of 194 cases with emphasis on the epithelioid histology and tuberous sclerosis association. Am J Surg Pathol. 2009;33:289-97.

27. Brimo F, Robinson B, Guo C, Zhou M, Latour M, Epstein Jl. Renal epithelioid angiomyolipoma with atypia: a series of 40 cases with emphasis on clinicopathologic prognostic indicators of malignancy. Am J Surg Pathol. 2010;34:715-22.

28. Lei JH, Liu LR, Wei Q, Song TR, Yang L, Yuan HC, Jiang Y, Xu H, Xiong SH, Han P. A Four-Year Follow-up Study of Renal Epithelioid Angiomyolipoma: A Multi-Center Experience and Literature Review. Sci Rep. 2015;5:10030.

\section{Figures}





Figure 1

CT image of the patients' abdominal organs. A, several enlarged lymph nodes were also noted (white arrow). B, a cystic-solid mass of $6.3 \star 5.5 * 6.7 \mathrm{~cm}$ was seen in the middle and lower pole of the left kidney with a noticeable enhancement of solid components and a patchy hemorrhagic focus. $C$ and $D$, the solid components and blood supply of the tumor can be well observed. CT =computed tomography. 

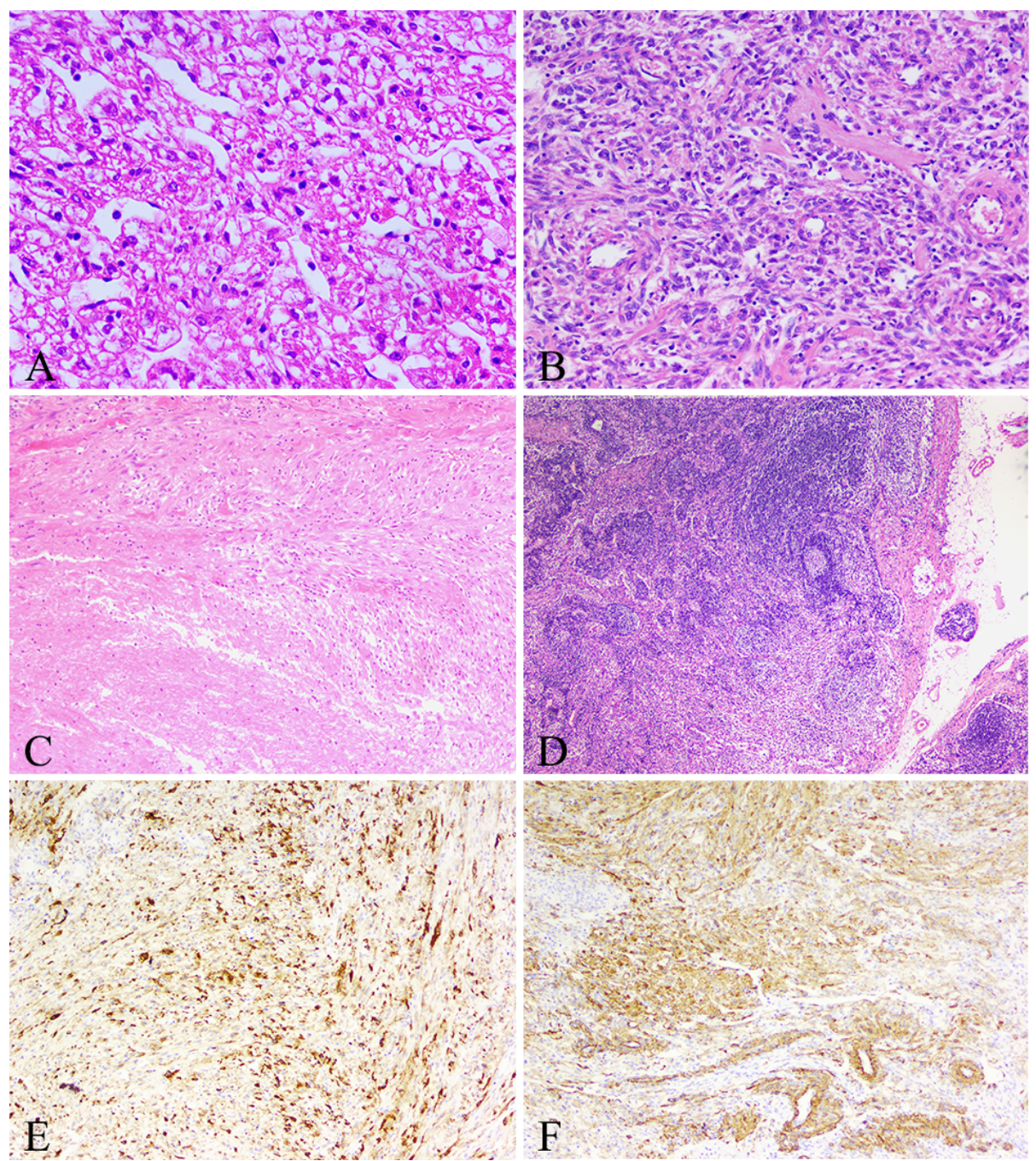

Figure 2

Histochemical and immunohistochemical features of the kidney. A, The typical PEComa area. B, Tumor cells with epithelioid appearance. C, Local necrotic area within the tumor. D, Lymph node metastasis $\times 40$. E, Tumor cells were strongly positive for MelanA. E, Tumor cells were strongly positive for SMA. 


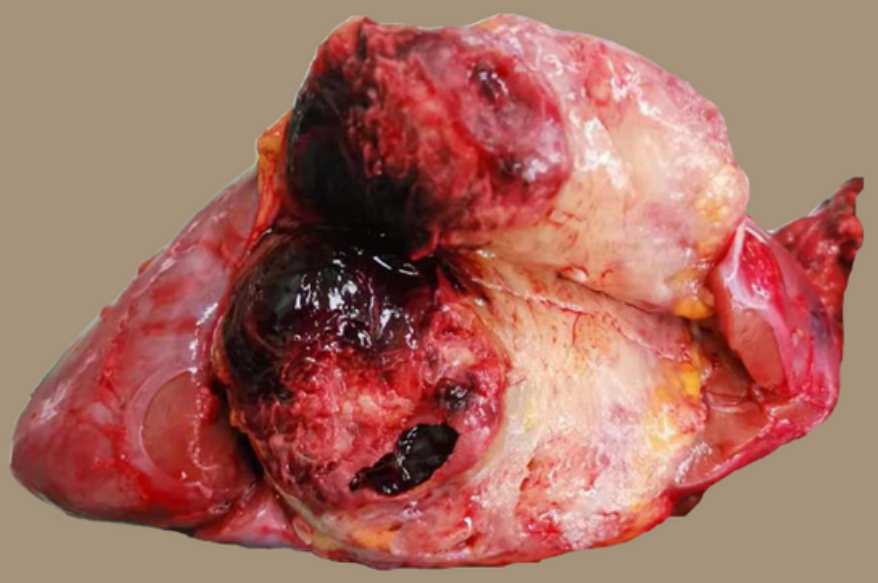

Figure 3

A mass with a clear boundary of approximately $6 \mathrm{~cm}$ in the renal hilum, as were $1.5 \mathrm{~cm}$ solid components including hemorrhagic and necrosis tissue. 